\title{
Nigella sativa fixed and essential oil modulates glutathione redox enzymes in potassium bromate induced oxidative stress
}

\author{
Muhammad Tauseef Sultan ${ }^{1}$, Masood Sadiq Butt ${ }^{2}$, Roselina Karim³ ${ }^{3}$ Waqas Ahmed ${ }^{2}$, Ubedullah Kaka ${ }^{4}$, Shakeel Ahmad',
} Saikat Dewanjee ${ }^{6}$, Hawa ZE Jaafar ${ }^{7^{*}}$ and M. Zia-UI-Haq ${ }^{8^{*}}$

\begin{abstract}
Background: Nigella sativa is an important component of several traditional herbal preparations in various countries. It finds its applications in improving overall health and boosting immunity. The current study evaluated the role of fixed and essential oil of Nigella sativa against potassium bromate induced oxidative stress with special reference to modulation of glutathione redox enzymes and myeloperoxidase.
\end{abstract}

Methods: Animals; 30 rats (Sprague Dawley) were divided in three groups and oxidative stress was induced using mild dose of potassium bromate. The groups were on their respective diets (iso-caloric diets for a period of 56 days) i.e. control and two experimental diets containing N. sativa fixed (4\%) and essential ( $0.3 \%)$ oils. The activities of enzymes involved in glutathione redox system and myeloperoxidase (MPO) were analyzed.

Results: The experimental diets modulated the activities of enzymes i.e. glutathione-S-transferase (GST), glutathione reductase (GR) and glutathione peroxidase (GPx) positively. Indices of antioxidant status like tocopherols and glutathione were in linear relationship with that of GPx, GR and GST $(P<0.01)$. MPO activities were in negative correlation with GST $(P<0.01)$ but positive correlation with some other parameters.

Conclusions: Our results indicated that both Nigella sativa fixed and essential oil are effective in improving the antioxidant indices against potassium bromate induced oxidative stress.

Keywords: Nigella sativa, Functional foods, Oxidative stress, Glutathione, Myeloperoxidase

\section{Background}

Since ages, communities relied on traditional medicines to prevent and cure various types of dietary health disorders. Scientists have realized now plant-based dietary interventions as the core heart epicenter of complimentary and alternative medicines. As the industrialization spun, the trends shifted towards reliance on pharmaceuticals. However, there are several societies across the globe who are more battened towards dietary therapeutic interventions $[1,2]$.

Nigella sativa L. (black cumin or black seeds) is good source of nutritionally essential components. Various

\footnotetext{
*Correspondence: hawazej@gmail.com; ahirzia@gmail.com

${ }^{7}$ Department of Crop Science, Faculty of Agriculture, University Putra Malaysia, Serdang, Selangor, Malaysia

${ }^{8}$ The Patent Office, Karachi, Pakistan

Full list of author information is available at the end of the article
}

cultures and civilizations utilize its seeds as herbal medicine to treat and prevent number of diseases [3]. Its health enhancing potentials are due to active ingredients (thymoquinone, carvacrol, thymol, cymene, $t$-anethole and 4-terpineol) that are mainly concentrated in fixed or essential oil [4]. Aforementioned bioactive components along with some others constituents possess notable antioxidant activity. $N$. sativa and its essential ingredient like thymoquinone are effective free radical scavengers in lipid peroxidation. Furthermore, they can also act as immune boosters and several research investigations have supported their anti-inflammatory and immunomodulatory effects [5].

The production of free radicals is an integral part of body metabolism but imbalance results is oxidative stress. The excessive lipid peroxidation results in destruction of cellular membranes that could leads to 
cell death and degenerative disorders [6]. The modulation of lipid peroxidation through natural body defense mechanism involving hepatic enzymes is of considerable importance. Previously, scientists elaborated that the $N$. sativa essential oil tends to normalize the level of lipid peroxidase (LPX), lactate dehydrogenase (LDH), glutathione (GSH), superoxide dismutase (SOD), glutathione peroxidase (GPx) and catalase (CAT) enzymes [7]. Some other researchers outlined the importance of $N$. sativa as antioxidant that could be useful in pathological conditions related to free radicals. However, the combination and in vivo role of oxidative stress and antioxidants is still a matter of conjecture. The antioxidant potential seems inversely linked with oxidative damage, however, the interactions between antioxidant potential of $N$. sativa in oxidative stress conditions needs research interventions conducted comprehensively. In this context, we have tried to study the role of Nigella sativa fixed and essential oils (NSFO \& NSEO) in improving the antioxidant status and attempted to explore their mechanisms and molecular targets. For the purpose, we measured the oxidative damage due to oxidative stress and determined the antioxidant potential of the body through measuring total antioxidant capacity (TAC), tocopherols, and glutathione contents. Later, we attempted to explore the mechanism and measured the glutathione redx enzymes expressions and myeleperoxidase activity.

\section{Methods}

Nigella sativa seeds were procured from Barani Agricultural Research Institute, Chakwal (Voucher specimen No. Chk.Pk-926) and preserved in the same institute for future reference. The seeds were further identified by Dr. Qasim Ali, Department of Botany, University of Agriculture, Faisalabad. Chemical Reagents (analytical \& HPLC grade) and standards were purchased from Sigma-Aldrich Tokyo, Japan and Merck KGaA, Darmstadt, Germany. The present research was conducted following the instructions of "Animal Care Committee, NIFSATFaisalabad Pakistan" (NIFSAT/ACC/07/16) and research plan was submitted to National Institute of Health (NIH), Islamabad for further approval of research. They provided infectious free Sprague dawley rats as per requirements of modified proposed research.

\section{Extraction of Nigella sativa fixed and essential oils}

Following the standard procedures, the seeds of Nigella sativa were slurred with hexane in 1:6 ratio (Soxtech apparatus and rotary evaporator) to extract the fixed oil. Nigella sativa essential oil was extracted using locally assembled hydro-distillation apparatus. Earlier to this manuscript, the authors published the results pertaining to the nutritional composition of NSFO and NSEO and safety assessment in Food and Chemical Toxicology [8].

\section{Housing of rats}

The National Institute of Health (NIH), Islamabad provided infectious free 30 Sprague Dawley rats that were further divided into three groups of ten rats each. The animals were maintained according to standard guidelines of Animal Institute of Nutrition (AIN), USA i.e. temperature $23 \pm 2{ }^{\circ} \mathrm{C}$, relative humidity $55 \pm 5 \%$, and 12-h light-dark cycle. In the first week, the feed of the rats was basal diet in order to acclimatize them to new environment. After the acclimatization period, rats received their respective experimental diets for a period of 8 weeks (56 days) (Table 1 ).

In order to induce oxidative stress in rats, the peritoneal injection of potassium bromate @ $45 \mathrm{mg} / \mathrm{Kg}$ body weight dissolved in $0.05 \mathrm{M}$ citrate buffer ( $\mathrm{pH} 4.5$ ) was employed. The analytical procedures carried out include feed \& water intake (measured daily) and body weight (weekly basis). At 28 \& 56 days of feeding trials, five rats from each group were decapitated for blood collection through neck and cardiac puncture [9]. The collected blood samples were analyzed for further assays and details are mentioned herein.

\section{Indices of oxidative damage}

Indicators of lipid peroxidation were estimated including MDA level [10], total antioxidant capacity [11] and conjugated dienes according to protocol described by Corongiu and Milla [12]. For total antioxidant capacity, we added reagent-1 (xylenol orange, $\mathrm{NaCl}$ and glycerol) in $35 \mu \mathrm{L}$ of collected serum and than added $11 \mu \mathrm{L}$ of reagent-2 (ferrous ion and o-dianisidine, $\mathrm{H}_{2} \mathrm{SO}_{4}$ solution) and readings were taken at $560 \mathrm{~nm}$ and $800 \mathrm{~nm}$. Briefly, MDA was measured with a colorimetric method using tetraethoxypropane as standard and units followed were $\mathrm{nmol} / \mathrm{mL}$. For the determination of conjugated dienes, serum was homogenized and centrifuged at $3000 \mathrm{~g}$. The spectra obtained (232-247 $\mathrm{nm}$ ) using hexane as standard solution was further used to estimate conjugated dienes and values were expressed in $\mathrm{nmol} / \mathrm{g}$ of lipids.

Table 1 Composition of control and experimental diets

\begin{tabular}{llll}
\hline Diet constituents & $\mathrm{D}_{1}$ & $\mathrm{D}_{2}$ & $\mathrm{D}_{3}$ \\
\hline Casein $(\mathrm{g})$ & 20.0 & 20.0 & 20.0 \\
Corn starch $(\mathrm{g})$ & 55.0 & 55.0 & 55.0 \\
Cellulose & 10.0 & 10.0 & 10.0 \\
Corn oil (g) & 10.0 & 6.0 & 10.0 \\
Nigella sativa fixed oil & - & 4.0 & - \\
Nigella sativa essential oil & - & - & 0.3 \\
Mineral mixture (g) & 4.0 & 4.0 & 4.0 \\
Vitamin mixture $(\mathrm{g})$ & 1.0 & 1.0 & 1.0 \\
Total diet weight $(\mathrm{g})$ & 100 & 100 & 100 \\
\hline
\end{tabular}

$\mathrm{D}_{1}=$ Control diet; $\mathrm{D}_{2}=$ Nigella sativa seed fixed oil; $\mathrm{D}_{3}=$ Nigella sativa seed essential oil 


\section{Indices of antioxidant status}

Glutathione contents were determined following the protocols described by Beutler [13]. In the protein free supernatant, the colored product of GSH + DTNB was measured at $412 \mathrm{~nm}$ and expressed as $\mathrm{nmol} / \mathrm{mg}$ protein. Level of serum $\alpha$-tocopherol and $\gamma$-tocopherol were also measured following the procedures described by $\mathrm{Xu}$ and Godber [14] through HPLC. Briefly, the oil samples were slurred in hexane as a first step. A normal phase HPLC column (250 mm $\times 4.6 \mathrm{~mm}, 5.0 \mu \mathrm{m}$ particle size) and mobile phase consisting of isooctane \& ethyl acetate $(96: 4 \mathrm{v} / \mathrm{v})$ was used for the purpose. Total run time and flow rate were $30 \mathrm{~min}$ and $1.0 \mathrm{~mL} / \mathrm{min}$, respectively. The detector was set at $290 \mathrm{~nm}$ excitation wavelength and $400 \mathrm{~nm}$ emission wavelengths. The column temperature was $35^{\circ} \mathrm{C}$. Similarly, the individual standards of isomers of tocopherols were run using the same pattern and curves were obtained and used for calibration in order to determine the amounts of tocopherols in Nigella sativa fixed oil.

\section{Superoxide dismutase and catalase enzymes assays}

The antioxidant enzymes assays include the estimation of Superoxide dismutase (SOD) and catalase. The measurement of SOD activity was based on the reaction between ability of enzyme to inhibit cytochrome ' $c$ ' oxidation [15] and activity was expressed in IU/mg protein. The decomposition of hydrogen peroxide and measurement of its by-products were mainly used for the estimation of catalase (CAT) activity. The units remained the same as IU/mg protein and $1 \mathrm{IU}$ was equivalent to $1 \mu \mathrm{mol} \mathrm{H}_{2} \mathrm{O}_{2}$ consumed per mg protein per minute [16].

\section{Glutathione redox enzymes assays}

Glutathione transferase (GST) action was measure using the commercial kits provided by Bioassay Internationals. The reaction include the rate of formation of conjugate between GSH and 1-chloro-2,4- dinitrobenzene [13] and measurement unit used IU/mg protein. The $1 \mathrm{IU}$ is equivalent to $1 \mu \mathrm{mol}$ of conjugate formed $/ \mathrm{min} / \mathrm{mg}$ protein. Glutathione peroxidase (GPx) activity was estimated using tertiary butyl hydroperoxide (tbHP) as substrate [17] and the activity was expressed in IU/mg protein. The $1 \mathrm{IU}$ is equivalent to one nmol of NADPH oxidized/mg protein in one minute. Glutathione reductase (GR) activity was assayed by estimating the oxidation of NADPH. Glutathione reductase (GR) activity was assayed at $37{ }^{\circ} \mathrm{C}$ and $340 \mathrm{~nm}$ by estimating the oxidation of NADPH. Hepatic enzymes like GST, GPx and GR was determined as described by Paglia and Valentine [18].

\section{Myeloperoxidase, xanthine oxidase, and nitric oxide} In this study, we used spectrophotometer to estimate the activity of tissue associated myeloperoxidase (MPO) following the procedures laid down by Hillegas et al. [19]. For the purpose, single unit of enzyme activity (IU/mg of proteins) was defined as the amount of the MPO present that caused a change in absorbance measured at $460 \mathrm{~nm}$ during the reaction time of three minutes. The indices like xanthine oxidase and nitric oxide are also of significance importance as far as immunopotentiating properties are concerned. We measured the xanthine oxidase using the using diagnostic kits from Cayman Chemicals.

\section{Statistical analysis}

Statistical package i.e. Cohort V-6.1 (Co-Stat Statistical Software, 2003) was used for data analysis. Briefly, values presented in Tables are means \pm standard deviation. In order to check the level of significance, analysis of variance (ANOVA) technique was applied. The diets (factor A), intervals (factor B) and their interaction $(A \times B)$ were used as source of variations (SOV). Duncan's multiple range test (DMRt) further clarified the effects of diets and intervals in a comprehensive manner.

\section{Results}

The onset of $21^{\text {st }}$ century witnessed the coinage of new terms like functional, nutraceutical and pharma foods. The awareness among the masses regarding the diethealth linkages improved significantly that further led scientists to conduct research studies. The present research intervention focused on exploring the role of Nigella sativa fixed oil (NSFO) and essential oil (NSEO) to improve antioxidant status and modulation of glutathione redox enzymes. The results pertaining to the different parameters presented herein.

\section{Indices of oxidative damage}

Diets affected total antioxidant capacity (TAC), serum MDA and conjugated dienes levels significantly, whilst non-momentous impact of study intervals was observed (Table 2). The maximum antioxidant capacity of $0.62 \pm$ $0.113 \mathrm{IU} / \mathrm{mL}$ was observed in groups of rats fed on $\mathrm{D}_{3}$ (N. sativa essential oil) followed by $0.52 \pm .0044 \mathrm{IU} / \mathrm{mL}$ in $\mathrm{D}_{2}$ ( $N$. sativa fixed oil), while minimum capacity of $0.40 \pm 0.045 \mathrm{IU} / \mathrm{mL}$ was recorded for control group. However, total antioxidant capacity decreased in control group during the course of study from $0.49 \pm 0.031$ to $0.34 \pm 0.021 \mathrm{IU} / \mathrm{mL}$ whereas increasing tendency from $0.44 \pm 0.028$ to $0.59 \pm 0.035$ and $0.43 \pm 0.017$ to $0.82 \pm$ $0.035 \mathrm{IU} / \mathrm{mL}$ was observed in fixed and essential oils groups, respectively. The maximum MDA level 19.04 \pm $1.54 \mathrm{nmol} / \mathrm{g}$ was recorded in $\mathrm{D}_{1}$ (control) followed by $13.97 \pm 0.93$ in $\mathrm{D}_{2}$ ( $N$. sativa fixed oil), while lowest serum MDA level of $10.53 \pm 2.47 \mathrm{nmol} / \mathrm{g}$ was recorded in $\mathrm{D}_{3}$ ( $N$. sativa essential oil). During the course of study, progressive increase in serum MDA level was 
Table 2 Indices of antioxidants damage in oxidative stressed rats

\begin{tabular}{|c|c|c|c|c|}
\hline \multirow[t]{2}{*}{ Parameters } & \multirow[t]{2}{*}{ Diets } & \multicolumn{3}{|c|}{ Study intervals (days) } \\
\hline & & 0 & 28 & 56 \\
\hline \multirow[t]{3}{*}{ Total antioxidants capacity (TAC) (IU/mL) } & $D_{1}$ & $0.49 \pm 0.031 \mathrm{~cd}$ & $0.38 \pm 0.027 \mathrm{ef}$ & $0.34 \pm 0.021 f$ \\
\hline & $D_{2}$ & $0.44 \pm 0.028 \mathrm{de}$ & $0.54 \pm 0.025 b c$ & $0.59 \pm 0.035 b$ \\
\hline & $D_{3}$ & $0.43 \pm 0.017 \mathrm{de}$ & $0.62 \pm 0.030 b$ & $0.82 \pm 0.035 a$ \\
\hline \multirow[t]{3}{*}{ MDA (nmol/g) } & $D_{1}$ & $16.90 \pm 1.08 \mathrm{c}$ & $18.21 \pm 1.31 b$ & $22.02 \pm 1.37 a$ \\
\hline & $D_{2}$ & $15.60 \pm 1.01 c$ & $13.92 \pm 0.65 d$ & $12.39 \pm 0.73 d$ \\
\hline & $D_{3}$ & $15.42 \pm 0.61 c$ & $8.70 \pm 0.42 \mathrm{e}$ & $7.46 \pm 0.32 \mathrm{e}$ \\
\hline \multirow[t]{3}{*}{ Conjugated dienes (CD) (nmol/g) } & $D_{1}$ & $5.60 \pm 0.359 b c$ & $6.05 \pm 0.436 b$ & $7.00 \pm 0.435 \mathrm{a}$ \\
\hline & $D_{2}$ & $5.48 \pm 0.353 b c$ & $5.07 \pm 0.237 \mathrm{~cd}$ & $4.60 \pm 0.270 \mathrm{e}$ \\
\hline & $D_{3}$ & $5.26 \pm 0.208 \mathrm{~cd}$ & $4.76 \pm 0.228 \mathrm{de}$ & $3.45 \pm 0.148 f$ \\
\hline
\end{tabular}

Means sharing same letters in a column/row do not differ significantly at $P<0.05$

observed in control group from $16.90 \pm 1.08$ to $22.02 \pm$ $1.37 \mathrm{nmol} / \mathrm{g}$. Diet containing essential oil showed marked decrease in serum MDA level from 15.42 \pm 0.61 to $7.46 \pm 0.32 \mathrm{nmol} / \mathrm{g}$ during entire study. Likewise, progressive decrease in MDA level was also observed in fixed oil group from $15.60 \pm 1.01$ to $12.39 \pm 0.73 \mathrm{nmol} / \mathrm{g}$ during 8 weeks study. Conjugated dienes varied differently among diets; group of rats fed on $N$. sativa fixed and essential oils showed significantly lower values i.e. $5.05 \pm 0.253$ and $4.49 \pm 0.538 \mathrm{nmol} / \mathrm{g}$, respectively as compared to maximum $6.22 \pm 0.413 \mathrm{nmol} / \mathrm{g}$ in control group. Furthermore, conjugated dienes increased from $5.60 \pm 0.359$ to $7.00 \pm 0.435 \mathrm{nmol} / \mathrm{g}$ in $\mathrm{D}_{1}$ group, while there observed decreasing trend from $5.48 \pm 0.353$ to $4.60 \pm 0.270$ and $5.26 \pm 0.208$ to $3.45 \pm 0.148 \mathrm{nmo} / \mathrm{g}$ in $\mathrm{D}_{2}$ and $\mathrm{D}_{3}$ groups, respectively.

\section{Indices of antioxidant status}

It is apparent from Table 3 that glutathione, $\alpha$ - and $\beta$ tocopherols contents altered significantly as a function of experimental diets, study intervals and their interaction. Diets containing $N$. sativa fixed and essential oils showed promising improvements in glutathione contents i.e. increased from $29.09 \pm 1.87$ to $30.34 \pm 1.78$ and $26.76 \pm 1.06$ to $32.60 \pm 1.39 \mathrm{mg} / \mathrm{L}$, respectively, during the whole study duration. However, there observed progressive decrease in glutathione contents in $\mathrm{D}_{1}$ (control) from $27.70 \pm 1.78$ to $20.71 \pm 1.29 \mathrm{mg} / \mathrm{L}$. Similarly, $\alpha$-Tocopherol contents decreased in control group significantly from $74.16 \pm$ 4.75 to $52.35 \pm 3.26 \mathrm{ng} / \mathrm{mL}$. However, diets containing fixed and essential oils improved the tocopherols contents momentously from $70.51 \pm 2.78$ to $80.29 \pm 3.43$ and $70.97 \pm 4.57$ to $76.59 \pm 4.50 \mathrm{ng} / \mathrm{mL}$, respectively.

Table $\mathbf{3}$ Indices of antioxidant status in oxidative stressed rats

\begin{tabular}{|c|c|c|c|c|}
\hline \multirow[t]{2}{*}{ Parameters } & \multirow[t]{2}{*}{ Diets } & \multicolumn{3}{|c|}{$\underline{\text { Study intervals (days) }}$} \\
\hline & & 0 & 28 & 56 \\
\hline \multirow[t]{3}{*}{ Total Glutathione (mg/L) } & $\mathrm{D}_{1}$ & $27.70 \pm 1.78 \mathrm{~cd}$ & $23.24 \pm 1.68 \mathrm{e}$ & $20.71 \pm 1.29 f$ \\
\hline & $D_{2}$ & $29.09 \pm 1.87 c$ & $28.03 \pm 1.31 \mathrm{~cd}$ & $30.34 \pm 1.78 b c$ \\
\hline & $D_{3}$ & $26.76 \pm 1.06 \mathrm{de}$ & $30.71 \pm 1.47 b$ & $32.60 \pm 1.39 a$ \\
\hline \multirow[t]{3}{*}{ Reduced Glutathione (mg/L) } & $D_{1}$ & $21.67 \pm 1.25$ & $17.80 \pm 0.58$ & $15.46 \pm 0.78$ \\
\hline & $D_{2}$ & $23.19 \pm 0.97$ & $22.96 \pm 0.77$ & $24.93 \pm 1.10$ \\
\hline & $D_{3}$ & $20.75 \pm 0.79$ & $25.33 \pm 1.23$ & $27.49 \pm 1.22$ \\
\hline \multirow[t]{3}{*}{ a-Tocopherol (ng/mL) } & $\mathrm{D}_{1}$ & $74.16 \pm 4.75 b c$ & $61.36 \pm 4.42 d$ & $52.35 \pm 3.26 \mathrm{e}$ \\
\hline & $\mathrm{D}_{2}$ & $70.51 \pm 2.78 c$ & $78.55 \pm 3.76 a$ & $80.29 \pm 3.43 a$ \\
\hline & $D_{3}$ & $70.97 \pm 4.57 c$ & $74.92 \pm 3.50 \mathrm{bc}$ & $76.59 \pm 4.50 \mathrm{ab}$ \\
\hline \multirow[t]{3}{*}{ Y-Tocopherol (ng/mL) } & $D_{1}$ & $15.12 \pm 0.97 \mathrm{~cd}$ & $14.97 \pm 1.08 \mathrm{~cd}$ & $12.01 \pm 0.75 \mathrm{e}$ \\
\hline & $D_{2}$ & $14.25 \pm 0.56 d$ & $16.58 \pm 0.79 b$ & $19.06 \pm 0.82 \mathrm{a}$ \\
\hline & $D_{3}$ & $14.12 \pm 0.91 d$ & $15.66 \pm 0.73 b c$ & $16.91 \pm 0.99 b$ \\
\hline
\end{tabular}

$D_{1}=$ Control diet; $D_{2}=N$. sativa seed fixed oil; $D_{3}=N$. sativa seed essential oil

Means sharing same letters in a column/row do not differ significantly at $P<0.05$ 
Likewise, $\gamma$-Tocopherol contents decreased from $15.12 \pm$ 0.97 to $12.01 \pm 0.75 \mathrm{ng} / \mathrm{mL}$ in $\mathrm{D}_{1}$, while increased from $14.25 \pm 0.56$ to $19.06 \pm 0.82$ and $14.12 \pm 0.91$ to $16.91 \pm$ $0.99 \mathrm{ng} / \mathrm{mL}$ in $\mathrm{D}_{2}$ and $\mathrm{D}_{3}$ groups, respectively.

\section{Superoxide dismutase and catalase enzymes assays}

The antioxidant enzymes including superoxide dismutase (SOD) and catalase (CAT) were significantly affected as a function of diets, study intervals and their interaction (Table 4). It is obvious from the results that SOD activity increased during the oxidative stress conditions that was more pronounced in control i.e. $17.66 \pm 1.13$ to $28.55 \pm 1.78 \mathrm{IU} / \mathrm{mg}$ protein. The fixed and essential oils restored their activities from $18.39 \pm 1.18$ to $17.32 \pm 1.02$ and $18.21 \pm 0.72$ to $16.12 \pm 0.69 \mathrm{IU} / \mathrm{mg}$ protein, respectively. The activity of catalase increased significantly in $D_{1}$ (control) from $6.04 \pm 0.376$ to $7.19 \pm$ $0.461 \mathrm{IU} / \mathrm{mg}$ protein, while the declining tendency from $8.10 \pm 0.476$ to $6.96 \pm 0.448$ and $10.83 \pm 0.419$ to $6.39 \pm$ $0.252 \mathrm{IU} / \mathrm{mg}$ protein was observed in $\mathrm{D}_{2}$ (N. sativa fixed oil) and $\mathrm{D}_{3}$ (N. sativa essential oil) groups, respectively (Table 4).

\section{Glutathione redox enzymes assays}

The experimental diets affected the enzyme expressions of glutathione peroxidase (GPx), glutathione reductase (GR) and glutathione transferase (GST) significantly (Table 4). However, GPx, GR and GST followed the opposite trend to SOD and catalase i.e. decreased significantly in control group from $65.60 \pm 4.206$ to $58.92 \pm$ $3.665,16.35 \pm 1.048$ to $14.70 \pm 0.914$ and $0.53 \pm 0.034$ to
$0.40 \pm 0.025 \mathrm{IU} / \mathrm{mg}$ protein, respectively (Table 4). Diets containing fixed and essential oils enhanced the expression of glutathione peroxidase significantly i.e. $58.01 \pm$ 3.737 to $72.68 \pm 4.269$ and $56.80 \pm 2.243$ to $80.79 \pm$ $3.456 \mathrm{IU} / \mathrm{mg}$ protein, respectively. Moreover, glutathione reductase increased from $14.48 \pm 0.932$ to $25.35 \pm 1.489$ and $14.62 \pm 0.560$ to $27.60 \pm 1.621 \mathrm{IU} / \mathrm{mg}$ protein. Likewise, glutathione transferase contents increased from $0.43 \pm 0.028$ to $0.61 \pm 0.036$ and $0.42 \pm 0.017$ to $0.73 \pm$ $0.031 \mathrm{IU} / \mathrm{mg}$ protein, respectively.

\section{Immuno-potentiating perspective}

The experimental diets affected xanthine oxidase, nitric oxide and myeloperoxidase significantly (Table 5). The maximum xanthine oxidase activity $(27.28 \pm 1.23 \mathrm{IU} / \mathrm{mg}$ protein) was observed in $\mathrm{D}_{1}$ (control) followed by $19.12 \pm$ $1.83 \mathrm{IU} / \mathrm{mg}$ protein in $\mathrm{D}_{2}$ ( $N$. sativa fixed oil), while the least activity of $15.19 \pm 2.96 \mathrm{IU} / \mathrm{mg}$ protein was recorded in $\mathrm{D}_{3}$ ( $N$. sativa essential oil). Xanthine oxidase activity decreased significantly in $\mathrm{D}_{2}$ and $\mathrm{D}_{3}$ groups from $22.77 \pm$ 1.47 to $17.44 \pm 1.02$ and $21.07 \pm 0.83$ to $10.91 \pm$ $0.47 \mathrm{IU} / \mathrm{mg}$ protein, respectively during 8 weeks. The nitric oxide was maximum $(36.40 \pm 2.25 \mathrm{nmol} / \mathrm{dL})$ in control followed by $32.38 \pm 1.30 \mathrm{nmol} / \mathrm{dL}$ in $\mathrm{D}_{2}$, while the minimum contents of $28.83 \pm 2.46 \mathrm{nmol} / \mathrm{dL}$ were noted in $\mathrm{D}_{3}$ group. For same trait, increasing tendency was observed in control from $32.92 \pm 2.11$ to $40.62 \pm$ $2.53 \mathrm{nmol} / \mathrm{dL}$ during 56 days of study. In contrast, $\mathrm{D}_{2}$ and $\mathrm{D}_{3}$ groups reduced the stress conditions by decreasing the nitric oxide level from $34.77 \pm 2.24$ to $30.31 \pm 1.78$ and $33.28 \pm 1.31$ to $24.80 \pm 1.06 \mathrm{nmol} / \mathrm{dL}$, correspondingly.

Table 4 Hepatic antioxidants enzymes in oxidative stressed rats

\begin{tabular}{|c|c|c|c|c|}
\hline \multirow[t]{2}{*}{ Parameters } & \multirow[t]{2}{*}{ Diets } & \multicolumn{3}{|c|}{ Study intervals (days) } \\
\hline & & 0 & 28 & 56 \\
\hline \multirow[t]{3}{*}{ SOD (IU/mg protein) } & $D_{1}$ & $17.66 \pm 1.13 c$ & $24.94 \pm 0.61 b$ & $28.55 \pm 1.78 \mathrm{a}$ \\
\hline & $D_{2}$ & $18.39 \pm 1.18 c$ & $18.09 \pm 0.84 c$ & $17.32 \pm 1.02 \mathrm{~cd}$ \\
\hline & $D_{3}$ & $18.21 \pm 0.72 c$ & $16.42 \pm 0.79 \mathrm{de}$ & $16.12 \pm 0.69 e$ \\
\hline \multirow[t]{3}{*}{ Catalase (IU/mg protein) } & $D_{1}$ & $6.04 \pm 0.376 \mathrm{e}$ & $6.40 \pm 0.462 \mathrm{e}$ & $7.19 \pm 0.461 \mathrm{de}$ \\
\hline & $D_{2}$ & $8.10 \pm 0.476 b c$ & $7.85 \pm 0.367 \mathrm{~cd}$ & $6.96 \pm 0.448 \mathrm{de}$ \\
\hline & $\mathrm{D}_{3}$ & $10.83 \pm 0.419 a$ & $8.83 \pm 0.423 b$ & $6.39 \pm 0.252 e$ \\
\hline \multirow[t]{3}{*}{ Glutathione peroxidase (IU/mg protein) } & $\mathrm{D}_{1}$ & $65.60 \pm 4.206 \mathrm{~cd}$ & $60.72 \pm 4.379 d$ & $58.92 \pm 3.665 d$ \\
\hline & $D_{2}$ & $58.01 \pm 3.737 d$ & $67.73 \pm 3.162 c$ & $72.68 \pm 4.269 \mathrm{bc}$ \\
\hline & $D_{3}$ & $56.80 \pm 2.243 d$ & $76.54 \pm 3.619 a b$ & $80.79 \pm 3.456 a$ \\
\hline \multirow[t]{3}{*}{ Glutathione reductase (IU/mg protein) } & $\mathrm{D}_{1}$ & $16.35 \pm 1.048 c$ & $15.11 \pm 1.089 \mathrm{~cd}$ & $14.70 \pm 0.914 d$ \\
\hline & $\mathrm{D}_{2}$ & $14.48 \pm 0.932 d$ & $24.38 \pm 1.138 b$ & $25.35 \pm 1.489 b$ \\
\hline & $D_{3}$ & $14.62 \pm 0.560 d$ & $26.55 \pm 1.271 \mathrm{a}$ & $27.60 \pm 1.621 a$ \\
\hline \multirow[t]{3}{*}{ Glutathione transferase (IU/mg protein) } & $D_{1}$ & $0.53 \pm 0.034 \mathrm{de}$ & $0.48 \pm 0.035 \mathrm{ef}$ & $0.40 \pm 0.025 f$ \\
\hline & $\mathrm{D}_{2}$ & $0.43 \pm 0.028 f$ & $0.56 \pm 0.026 d$ & $0.61 \pm 0.036 c$ \\
\hline & $D_{3}$ & $0.42 \pm 0.017 f$ & $0.67 \pm 0.032 b$ & $0.73 \pm 0.031 a$ \\
\hline
\end{tabular}


Table $\mathbf{5}$ Indices of immune system in oxidative stressed rats

\begin{tabular}{|c|c|c|c|c|}
\hline \multirow[t]{2}{*}{ Parameters } & \multirow[t]{2}{*}{ Diets } & \multicolumn{3}{|c|}{ Study intervals (days) } \\
\hline & & 0 & 28 & 56 \\
\hline \multirow[t]{3}{*}{ Xanthine oxidase (IU/mg protein) } & $D_{1}$ & $24.98 \pm 1.60 \mathrm{bc}$ & $27.69 \pm 2.00 \mathrm{ab}$ & $29.17 \pm 1.81 a$ \\
\hline & $\mathrm{D}_{2}$ & $22.77 \pm 1.47 c$ & $17.15 \pm 0.80 d$ & $17.44 \pm 1.02 d$ \\
\hline & $D_{3}$ & $21.07 \pm 0.83 c$ & $14.90 \pm 0.71 \mathrm{e}$ & $10.91 \pm 0.47 e$ \\
\hline \multirow[t]{3}{*}{ Nitric oxide (nmol/dL) } & $D_{1}$ & $32.92 \pm 2.11 d$ & $35.66 \pm 2.57 b$ & $40.62 \pm 2.53 a$ \\
\hline & $D_{2}$ & $34.77 \pm 2.24 b c$ & $32.05 \pm 1.50 d$ & $30.31 \pm 1.78 \mathrm{ef}$ \\
\hline & $D_{3}$ & $33.28 \pm 1.31 \mathrm{~cd}$ & $28.40 \pm 1.36 f$ & $24.80 \pm 1.06 \mathrm{~g}$ \\
\hline \multirow[t]{3}{*}{ MPO (IU/mg protein) } & $\mathrm{D}_{1}$ & $18.91 \pm 1.212 \mathrm{C}$ & $20.05 \pm 1.446 b$ & $22.82 \pm 1.420 \mathrm{a}$ \\
\hline & $D_{2}$ & $19.43 \pm 1.252 \mathrm{bc}$ & $18.93 \pm 0.884 c$ & $16.07 \pm 0.944 d$ \\
\hline & $D_{3}$ & $20.62 \pm 0.814 a b$ & $16.14 \pm 0.772 d$ & $13.68 \pm 0.585 \mathrm{e}$ \\
\hline
\end{tabular}

$D_{1}=$ Control diet; $D_{2}=N$. sativa seed fixed oil; $D_{3}=N$. sativa seed essential oil

Means sharing same letters in a column/row do not differ significantly at $P<0.05$

The activity of MPO increased in $\mathrm{D}_{1}$ with the passage of time i.e. $18.91 \pm 1.212$ to $22.82 \pm 1.420 \mathrm{IU} / \mathrm{mg}$ protein during study duration. In contrary, $\mathrm{D}_{2}$ (N. sativa fixed oil) and $\mathrm{D}_{3}$ (N. sativa essential oil) groups showed decrease in MPO activity from $19.43 \pm 1.252$ to $16.07 \pm 0.944$ and $20.62 \pm 0.814$ to $13.68 \pm 0.585 \mathrm{IU} / \mathrm{mg}$ protein, respectively (Table 5).

\section{Discussion}

The diet and health linkages are well defined and many research studies carried out in animal and humans provided evidences that dietary modules are best strategy in preventing many ailments e.g. cardiovascular disorders and diabetes mellitus [4]. Nigella sativa is famous in Asian countries owing to its potential role in prevention of different ailments. In this regard, Sultan et al. [8] carried out the safety assessment of Nigella sativa fixed and essential oil (NSFO \& NSEO). In the present research, further efforts were made to study the effects of NSFO and NSEO on hepatic enzymes, antioxidant status and immunopotentiating potential of Nigella sativa in oxidative stressed Sprague dawley rats. The protocols followed in the present research were based on the studies conducted by scientists [20, 21].

In the present study, we fed the groups of rats on experimental diets containing $N$. sativa fixed and essential oils along with control for a period of 8 weeks. The addition of $N$. sativa fixed and essential oil increased feed and water intakes as compared to control group that certainly be due to the remedial action of experimental diets thus resulting in restoration of normal metabolism and body homeostasis [22-24]. Oxidation and its complexities results in uncontrolled free radicals production that become lethal leading to oxidative stress. In this regard, these reactive oxygen species (ROS) overcomes the antioxidant capacity of the target cells and tissues. In stress-induced conditions, supplementation of antioxidants may evoke certain protective roles in the body against various health discrepancies [25]. In the instant study, total antioxidant capacity (TAC) of the body decreased significantly in control group, while values for serum MDA and conjugated dienes levels increased indicating more oxidative damage. However, diets containing $N$. sativa fixed and essential oils assuaged the damage by improving total antioxidant capacity by 1.5 and 2.0 folds, respectively. Moreover, serum MDA level decreased significantly by 20.58 and $51.62 \%$ in fixed and essential oils groups, respectively. The conjugated dienes levels also decreased significantly i.e. 15.98 and $34.35 \%$, respectively. However, levels of serum MDA and conjugated dienes were higher as compared to normal rats owing to injection of potassium bromate used for induction of oxidative stress [8]. Total antioxidant capacity (TAC) is primarily dependent on antioxidants defence system capabilities and secondly on antioxidants ingested as a part of the diet. Moreover, it also relies on total free radical trapping potential of the body in both normal and oxidative stress conditions. The decreased TAC in oxidative stressed rats can be due to depletion of antioxidants present in the body and increased free radical production. Correlation also provided the evidence that MDA and conjugated dienes were negatively associated with TAC. The investigations conducted by Al-Othman et al. [26] proved that black cumin supplementations hold potential to improve the antioxidant capacity of the body. Antioxidant status i.e. glutathione, $\alpha$ - and $\gamma$-tocopherols were improved consequently with experimental diets. Level of glutathione decreased in control by $25.23 \%$, while increased by 4.30 and $21.82 \%$ in $N$. sativa fixed and essential oils groups, respectively. The restoration of glutathione to near normal ranges is hallmark of the present study. Glutathione along with tocopherols were in linear linkage with antioxidant capacity, while inverse association with that of oxidative damage. These findings further validated our stance that supplementation of diets rich in tocopherols and antioxidant ameliorate the adverse 
consequences of oxidative stress. Production of free radicals results in lipid peroxidation thus resulting in extensive oxidative damage as indicated by high level of MDA \& conjugated dienes. These indicators were modulated in groups of rats consuming fixed and essential oil based diets. According to Alenzi et al. [27], the oils of black cumin and thymoquinone served a protective mechanism against toxicity induced by cyclophosphamide and prevent incidence of necrosis. Formerly, Meral and Kanter [28] observed reduced level of MDA, improved antioxidant capacity and restoration of glutathione because of black cumin supplementation that strengthened the present results.

Lipid peroxides and associated moieties are products of lipid peroxidation that are harmful in progression of diseases such as atherosclerosis and brain damage. However, experimental diets attenuated the damage that certainly be attributed to their rich nutritional profile. In this context, El-Desoky et al. [29] suggested the potential role of tocopherols and nutraceuticals in scavenging free radicals and ameliorating their toxic effects for normal functionality of the body. In another research investigation, Sánchez-Reus et al. [30] reported that oxido-reduction or GSH/GSSG ratio is important in controlling the antioxidant potential of the body. In the present study, NSFO and NSEO modulated the hepatic enzymes activity. The aforementioned results indicated the involvement of complex mechanism in which specialized processes involving glutathione and tocopherols scavenge the oxidants like MDA, lipid peroxides, hydro-peroxides and conjugated dienes. The expressions of hepatic enzymes enhance the antioxidant capacity in the groups of rats fed on experimental diets. In this context, glutathione reductase (GR), glutathione peroxidase (GPx) and glutathione transferase (GST) are important biological catalyst to control peroxides and free radicals production through glutathione cyclic transformation [31].

Role of enzymes in amelioration of oxidative stress is indispensable. Casalino et al. [32] supported the present findings that antioxidant supplementation could avert the hepotocellular damage as a consequences of oxidative stress. The enhanced level of these metabolites triggers cascade of events that results in malfunctioning of the body and even in severe cases death may be the possible penalty. The supplementations of diets with appropriate antioxidant or formulation containing bioactive compounds are useful in reversing the sequential distortion due to free radicals. Some other studies also suggested that active ingredients present in $N$. sativa fixed and essential oils protect the body from nephrotoxicity and hepatotoxicity [4]. N. sativa fixed and essential oils ameliorate oxidative stress and maintain body homeostasis by regulating several hematological and serological attributes. The present exploration concluded that $N$. sativa fixed and essential oils have potential to improve the antioxidant status of the body. The diet supplemented with the $N$. sativa oils with special reference to essential oil can act as safeguard against oxidative stress and allied disorders. Future perspectives include testing their effectiveness as nutraceuticals in maladies characterized by oxidative stress like arthritis and osteoporosis.

\section{Conclusion}

Conclusive approach drawn from this efficacy study is, Nigella sativa fixed and essential oils hold potential to improve the antioxidant status and decrease antioxidant damage significantly in potassium bromate induced oxidative stressed rats. The oxidative stress and ROS induced negative changes in enzyme expressions but experimental diets modulated hepatic enzymes and immune system including GR, Gpx, GST, MPO, and xanthine oxidase positively. However, there is need to conduct further trials in other types of animal modeling to validate the findings.

\section{Competing interests}

The authors declare that they have no competing interests.

\section{Authors' contributions}

MTS, MSB,RK and WA conceptualized and performed the study, UK and SA analyzed the data, SD, HZEJ and MZ did data analysis and manuscript writing. All authors read and approved the final manuscript.

\section{Acknowledgments}

Higher Education Commission (HEC), Pakistan, supported this study. We thank all the members of our research team for their hard work and valuable assistance.

\section{Author details}

${ }^{1}$ Institute of Food Science and Nutrition, Bahauddin Zakariya University, Multan, Pakistan. ${ }^{2}$ National Institute of Food Science and Technology, University of Agriculture, Faisalabad, Pakistan. ${ }^{3}$ Faculty of Food Science \& Technology, University of Putra Malaysia, Serdang, Selangor, MY, Malaysia. ${ }^{4}$ Faculty of Veterinary Medicines, University of Putra Malaysia, Serdang, Selangor, Malaysia. ${ }^{5}$ Department of Agronomy, Bahauddin Zakariya University Multan, Multan, Pakistan. ${ }^{6}$ Advanced Pharmacognosy Research Laboratory, Department of Pharmaceutical Technology, Jadavpur University, Kolkata 700032, India. ${ }^{7}$ Department of Crop Science, Faculty of Agriculture, University Putra Malaysia, Serdang, Selangor, Malaysia. ${ }^{8}$ The Patent Office, Karachi, Pakistan.

Received: 5 April 2015 Accepted: 7 September 2015 Published online: 18 September 2015

\section{References}

1. Sultan MT, Butt MS, Qayyum MM, Suleria HA. Immunity: plants as effective mediators. Crit Rev Food Sci Nutr. 2014;54(10):1298-308.

2. Andersen CJ, Fernandez ML. Dietary strategies to reduce metabolic syndrome. Rev Endocr Metab Disord. 2013;14:241-54.

3. Sultan MT, Butt MS, Ahmad RS, Pasha I, Ahmad AN, Qayyum MM. Supplementation of Nigella sativa fixed and essential oil mediates potassium bromate induced oxidative stress and multiple organ toxicity. Pak J Pharm Sci. 2012;25:175-81.

4. Butt MS, Sultan MT. Nigella sativa reduces the risk of various maladies. Crit Rev Food Sci Nutr. 2010;50:654-65.

5. Shabana A, El-Menyar A, Asim M, Al-Azzeh H, Al TH. Cardiovascular benefits of Black Cumin (Nigella sativa). Cardiovasc Toxicol. 2013;13:9-21. 
6. Zia-Ul-Haq M, Ahmad S, Bukhari SA, Amarowicz R, Ercisli S, Jaafar HZE. Compositional studies and biological activities of some mash bean (Vigna mungo (L.) Hepper) cultivars commonly consumed in Pakistan. Biol Res. 2014;47:23-31.

7. Ahmad A, Husain A, Mujeeb M, Khan SA, Najmi AK, Siddique NA, et al. A review on therapeutic potential of Nigella sativa: a miracle herb. Asian Pac J Trop Biomed. 2013;3:337-52.

8. Sultan MT, Butt MS, Anjum FM. Safety assessment of Nigella sativa fixed and essential oils in normal Sprague Dawley: serological and hematological indices. Food Chem Toxicol. 2009:47:2768-75.

9. Uchida K, Satoh T, Ogura Y, Yamaga N, Yamada K. Effect of partial ileal bypass on cholesterol and bile acid metabolism in rats. Yanago Acta Medica. 2001:44:69-77.

10. Ohkawa N, Ohishi J, Yagi K. Assay for lipid peroxides in animal tissues by thiobarbituric acid reaction. Anal Biochem. 1979;95:351-8.

11. Hermes-Lima M, Willmore WG, Storey KB. Quantification of lipid peroxidation in tissue extracts based on Fe(III)xylenol orange complex formation. Free Radic Biol Med. 1995;19:271-80.

12. Corongiu FP, Milla A. An improved method for determining diene conjugation in autoxidized polyunsaturated fatty acids. Chem Biol Interact. 1983;44:289-97.

13. Beutler E. A manual of biochemical methods. New-York, USA: Grune and Stratton Publisher; 1982.

14. $\mathrm{Xu} \mathrm{Z,} \mathrm{Godber} \mathrm{JS.} \mathrm{Purification} \mathrm{and} \mathrm{identification} \mathrm{of} \mathrm{components} \mathrm{of}$ gamma-oryzanol in rice bran oil. J Agric Food Chem. 1999;47:2724-8.

15. Sun Y, Oberley LW, Li Y. A simple method for clinical assay of superoxide dismutase. Clin Chem. 1988:34:497.

16. Block PP, Karmer R, Paverka M. A simple assay for catalase determination. Cell Biol Monog. 1980;7:44-7.

17. Tappel AL. Glutathione peroxidase and hydroperoxides. Method Enzym. 1978:52:506-13.

18. Paglia DE, Valentine WN. Studies on the quantitative and qualitative characterization of erythrocyte glutathione peroxidase. J Lab Clin Med. 1967;70:158-69.

19. Hillegas LM, Griswold DE, Brickson B, Albrightson-Winslow C. Assessment of myeloperoxidase activity in whole rat kidney. J Pharmacol Meth. 1990;24:285-95.

20. Singh AS, Pal DT, Mandal BC, Singh P, Pathak NN. Studies on changes in some of blood constituents of adult cross-bred cattle fed different levels of extracted rice bran. Pak J Nutr. 2002;1:95-8.

21. Morita O, Tamaki Y, Kirkpatrick JB, Chengelis CP. Safety assessment of heated diacylglycerol oil: Subchronic toxicity study in rats. Food Chem Toxicol. 2008;46:2748-57.

22. Wajs A, Bonikowski R, Kalemba D. Composition of essential oil from seeds of Nigella sativa L. cultivated in Poland. Flav Frag J. 2008;23:126-32.

23. Khan SH, Ansari J, Abbas G. Black cumin seeds as phytogenic product in broiler diets and its effects on performance blood constituents immunity and caecal microbial population. Ital J Anim Sci. 2012;11:e77.

24. Wu T, Qi X, Liu Y, Guo J, Zhu R, Chen W, et al. Dietary supplementation with purified mulberry (Morus australis Poir) anthocyanins suppresses body weight gain in high-fat diet fed C57BL/6 mice. Food Chem. 2013;141:482-7.

25. Lönn ME, Dennis JM, Stocker R. Actions of 'antioxidants' in the protection against atherosclerosis. Free Radic Biol Med. 2012;53:863-84.

26. Al-Othman AM, Ahmad F, Al-Orf SK, Al-Murshed AZ. Effect of dietary supplementation of Ellataria cardamomum and Nigella sativa on the toxicity of rancid corn oil in Rats. Int J Pharmacol. 2006;2:60-5.

27. Alenzi FQ, El-Bolkiny YS, Salem ML. Protective effects of Nigella sativa oil and thymoquinone against toxicity induced by the anticancer drug cyclophosphamide. Br J Biomed Sci. 2010;67:20-8.

28. Meral I, Kanter M. Effects of Nigella sativa L. and Urtica dioica L. on selected mineral status and hematological values in $\mathrm{CCl}_{4}$-treated rats. Biol Trace Elem Res. 2003;96:263-70.

29. El-Desoky G, Abdelreheem M, Abdulaziz AL, ALOthman Z, Mahmoud M, Yusuf K. Potential hepatoprotective effects of vitamin $E$ and selenium on hepatotoxicity induced by malathion in rats. Af J Pharm Pharmacol. 2012;6:806-13.
30. Sánchez-Reus MI, del Rio G, Iglesias MA, Elorza I, Slowing M, Benedí K. Standardized Hypericum perforatum reduces oxidative stress and increases gene expression of antioxidant enzymes on rotenone-exposed rats. Neuropharmacology. 2007;52:606-16.

31. Das L, Bhaumik E, Raychaudhuri U, Chakraborty R. Role of nutraceuticals in human health. J Food Sci Technol. 2012;49:173-83.

32. Casalino E, Sblano C, Calzaretti G, Landriscina C. Acute cadmium intoxication induces alpha-class glutathione S-transferase protein synthesis and enzyme activity in rat liver. Toxic. 2006;217:240-5.

\section{Submit your next manuscript to BioMed Central and take full advantage of:}

- Convenient online submission

- Thorough peer review

- No space constraints or color figure charges

- Immediate publication on acceptance

- Inclusion in PubMed, CAS, Scopus and Google Scholar

- Research which is freely available for redistribution 